Original article

\title{
The gas-test technique as a tool for predicting the energetic value of forage plants
}

\author{
Michel Chenost, Jocelyne Aufrère*, Didier MACHEBOEUF
}

INRA, Unité de Recherches sur les Herbivores, 63122 Saint-Genès-Champanelle, France

(Received 12 February 2001; accepted 10 September 2001)

\begin{abstract}
Seventy-nine forages of known in vivo organic matter digestibility (OMD) out of which 45 of known voluntary dry matter intake (DMI) all measured with sheep, were submitted to the in vitro gas production (GP) technique. The aim was to study the prediction accuracy $\left(R^{2}, \mathrm{RSD}\right)$ of the nutritive value of the main components of forages that is, OMD, DMI and voluntary digestible organic matter intake (DOMI). This accuracy was compared with that obtained with the pepsin cellulase method (Cellulase). It appeared necessary to consider the forages by category (grasses or legumes and green forages or hays) in order to obtain a better accuracy in OMD prediction. The " $(\mathrm{a}+\mathrm{b})$ " value of the GP model $=\mathrm{a}+\mathrm{b}\left(1-\mathrm{e}^{-\mathrm{ct}}\right)$ used to fit the data did not appropriately predict OMD, which was much better predicted from the "c" value (related to the rate of fermentation) or by Cellulase. For grass hays, the OMD was already well predicted by GP $24 \mathrm{~h} \times \mathrm{CP}$ (gas produced after 24 hours $\times$ crude protein content). The accuracy of digestibility prediction was improved by adding $\mathrm{CP}$ as a complementary variable except with lucerne hays. The relationships between DMI and gas production (at a given time or at the end of fermentation) were fair and not really improved by adding CP content. However, the accuracy of DOMI prediction was slightly better with " $\mathrm{c}$ " $\times \mathrm{CP}$ than with Cellulase for green grasses and grass hays, although Cellulase was better for DOMI prediction of whole lucerne. Although the gas production technique was less efficient than Cellulase to predict OMD it is an interesting technique for predicting voluntary DOMI, that is the global nutritive value of forages.
\end{abstract}

prediction / organic matter digestibility / ingestibility / in vitro gas production / Cellulase / forages / ruminant

Résumé - Utilisation de la technique du gaz-test comme outil de prévision de la valeur énergétique des fourrages. L'objectif de cette étude a été de mesurer la précision de la méthode de la production de gaz (GP) in vitro pour prévoir la valeur énergétique des fourrages et de comparer celle-ci à la méthode pepsine-cellulase (Cellulase). Soixante-dix-neuf fourrages dont la digestibilité in vivo de la matière organique (OMD) était connue ont été utilisés comme substrats. Les valeurs des quantités volontairement ingérées (DMI) étaient connues pour 45 des fourrages. Les substrats étaient fermentés dans des seringues avec le fluide ruminal et la production de gaz était relevée 3, 6, 12, 24, $48,72,96$ heures après inoculation. Il est apparu nécessaire de considérer les fourrages par catégories

* Correspondence and reprints

Tel.: 33 (0)4 736240 72; fax: 33 (0)4 7362 42 73; e-mail: aufrere @ clermont.inra.fr 
(graminées ou luzerne, foin ou fourrage vert) pour obtenir une meilleure précision dans la prévision de OMD. La valeur $(\mathrm{a}+\mathrm{b})$ du modèle $\mathrm{GP}=\mathrm{a}+\mathrm{b}\left(1-\mathrm{e}^{-\mathrm{ct}}\right)$ utilisé pour l'ajustement des données, n'est pas appropriée pour la prévision de OMD. La relation est plus précise avec le paramètre «c » (relatif à une vitesse de fermentation) ou avec la Cellulase. Dans le cas du foin de graminées, OMD est déjà bien estimée dès 24 heures par GP $24 \mathrm{~h} \times \mathrm{CP}$ (production de gaz à $24 \mathrm{~h} \times$ teneur en matières azotées). La précision de la prévision de OMD est améliorée par l'introduction de CP excepté pour les foins de luzerne. Les relations entre DMI et GP ne sont pas très bonnes et pas vraiment améliorées par l'introduction de $\mathrm{CP}$ dans la régression. Cependant, la précision de la prévision de DOMI (matière organique digestible ingérée) avec $« \mathrm{c} » \times \mathrm{CP}$ a été légèrement supérieure à celle obtenue avec la Cellulase pour les fourrages verts et les foins de graminées alors que celle-ci a été meilleure avec la Cellulase dans le cas des luzernes. Bien que la technique de production de gaz in vitro soit moins efficace que la Cellulase pour prévoir OMD, c'est une technique intéressante pour prévoir DOMI i.e. valeur nutritive globale du fourrage mais sa précision est essentiellement due à OMD plutôt qu'à DMI.

prévision / digestibilité de la matière organique / ingestibilité / fourrage / gaz-test / Cellulase / ruminant

\section{INTRODUCTION}

The gas production (GP) technique [27, 28 ] is used more and more to predict (for preliminary in vitro studies) the fermentative digestion of feeds or rations in the rumen. It is also becoming popular for predicting the nutritive value of forages. The advantages of the GP technique over other in vitro techniques [32] for feed evaluation have been outlined by Blümmel and Ørskov [10] and Makkar et al. [26]. The relationships observed by Khazaal et al. [23] between in vivo data and prediction measurements on grasses and legume hays are, however, less accurate with the GP technique than with the in situ technique. More particularly, and as underlined by Blümmel and Bullerdieck [9], the prediction of voluntary intake from the fermentation rate as a predictor of the rate of degradation - and therefore of intake - suffers from the bias introduced by the synthesis of microbial biomass. This observation led these authors to introduce a correction factor related to residues of in situ degradabilities.

The aim of this study was to evaluate the accuracy of the GP technique in predicting organic matter digestibility (and intake, when available) on various types of forages in comparison with the pepsin-cellulase method (Cellulase).

\section{MATERIALS AND METHODS}

\subsection{In vivo measurements}

In vivo organic matter digestibility (OMD) measurement was performed on six mature 3 or 4-year-old wethers. Digestibility and voluntary dry matter intake (DMI) measurements were done, according to Demarquilly and Jarrige [16], for 6 days after an adaptation period of 10 days, each period being separated by Sunday. The voluntary digestible organic matter intake (DOMI) was calculated as the product of OMD and DMI.

During the experimental periods, the animals were housed in individual cages $\left(2.5 \mathrm{~m}^{2}\right)$ on wood shaving litter and allowed free access to water and a salt block. The animals were given the forage in a chopped form. They were fed two meals per day ad libitum (10\% refusal) at $09.00 \mathrm{~h}$ and $17.00 \mathrm{~h}$.

\subsection{Samples}

Seventy-nine forages (24 green (G) grasses, 38 grass hays $(\mathrm{H}), 5 \mathrm{G}$ lucernes and $12 \mathrm{H}$ lucernes) of OMD out of which 45 (17 G grasses, $16 \mathrm{H}$ grasses, $5 \mathrm{G}$ lucernes and 7 H lucernes) of known DMI, all measured with sheep, were chosen with varying OMD 
(from 49.0 to $80.8 \%$ ) and crude protein (CP) content of dry matter (DM), (CP from 48 to $\left.253 \mathrm{~g} \cdot \mathrm{kg}^{-1} \mathrm{DM}\right)$. Their characteristics are given in Table I.

\subsection{Gas production measurement}

\subsubsection{Fistulated donor animals and rumen liquors}

Rumen liquor was obtained from two rumen-fistulated sheep (65 kg liveweight) maintained in cages $\left(2.5 \mathrm{~m}^{2}\right)$ with wood shavings litter and fed $1 \mathrm{~kg} \cdot \mathrm{d}^{-1}$ (fractionated into two equal meals per day) of a cocksfoot regrowth hay of $153 \mathrm{~g} \mathrm{CP} \cdot \mathrm{kg}^{-1} \mathrm{DM}$. The liquor, sampled $1 \mathrm{~h}$ after the morning meal, was strained through 4 layers of cheesecloth and the filtrate was maintained at $39{ }^{\circ} \mathrm{C}$ under $\mathrm{CO}_{2}$ reflux before use.

\subsubsection{Inoculum preparation}

The inoculum was prepared as described by Menke and Steingass [27]. It consisted of the rumen liquor mixed $(1: 2 \mathrm{v} / \mathrm{v})$ with anaerobic artificial saliva. The latter included, for a final volume of 1 litre, $237 \mathrm{~mL}$ of buffer solution, $237 \mathrm{~mL}$ of a main element solution,
$0.12 \mathrm{~mL}$ of a trace element solution, $1.22 \mathrm{~mL}$ of resazurin solution (100 $\mathrm{mg}$ resazurin made up to $100 \mathrm{~mL}$ distilled water), $49.5 \mathrm{~mL}$ of a reduction solution (prepared fresh and separately and consisting of $2 \mathrm{~mL}$ of $\mathrm{NaOH} 1 \mathrm{~N}, 285 \mathrm{mg}$ of $\mathrm{Na}_{2} \mathrm{~S}-7 \mathrm{H}_{2} \mathrm{O}$ and $47.5 \mathrm{~mL}$ distilled water for $1 \mathrm{~L}$ saliva), completed with $475 \mathrm{~mL}$ of distilled water. The buffer solution consisted of $\mathrm{NaHCO}_{3}$ $35 \mathrm{~g} \cdot \mathrm{L}^{-1}$ and $\mathrm{NH}_{4} \mathrm{HCO}_{3} 4 \mathrm{~g} \cdot \mathrm{L}^{-1}$. The main element solution consisted of $\mathrm{Na}_{2} \mathrm{HPO}_{4}$ $5.70 \mathrm{~g} \cdot \mathrm{L}^{-1}, \mathrm{KH}_{2} \mathrm{PO}_{4} 6.20 \mathrm{~g} \cdot \mathrm{L}^{-1}$ and $\mathrm{Mg}$ $\mathrm{SO}_{4}-7 \mathrm{H}_{2} \mathrm{O} 0.60 \mathrm{~g} \cdot \mathrm{L}^{-1}$. The trace element solution consisted of $\mathrm{CaCl}_{2}-2 \mathrm{H}_{2} \mathrm{O} 13.20 \mathrm{~g}$, $\mathrm{MnCl}_{2}-4 \mathrm{H}_{2} \mathrm{O} 10.00 \mathrm{~g}, \mathrm{CoCl}_{2}-6 \mathrm{H}_{2} \mathrm{O} 1.00 \mathrm{~g}$ and $\mathrm{FeCl}_{2}-6 \mathrm{H}_{2} \mathrm{O} 0.80 \mathrm{~g}$ made up to $100 \mathrm{~mL}$ with distilled water.

The rumen liquor was incorporated in the medium once the reduction process was achieved (resazurin decoloration after adding the reduction solution). All manipulations were done under continuous $\mathrm{CO}_{2}$ reflux.

\subsubsection{Incubation and gas production measurements}

About $200 \pm 10 \mathrm{mg}$ dry weight of substrate sample were weighted into $100 \mathrm{~mL}$ calibrated glass syringes. The syringes,

Table I. Characteristics, average and extreme values of crude protein (CP) and crude fibre (CF) contents and in vivo organic matter (OMD) and in vitro cellulase (Cellulase) digestibility of forages used.

\begin{tabular}{|c|c|c|c|c|c|}
\hline \multirow[t]{2}{*}{ Categories } & \multirow[t]{2}{*}{ Number } & Crude protein & Crude fibre & Cellulase & OMD \\
\hline & & \multicolumn{2}{|c|}{$\% \mathrm{DM}$} & \multicolumn{2}{|c|}{$\%$} \\
\hline Green grasses & 24 & $\begin{array}{c}15.4 \\
(8.2-21.6)\end{array}$ & $\begin{array}{c}26.9 \\
(19.2-37.3)\end{array}$ & $\begin{array}{c}64 \\
(47-81)\end{array}$ & $\begin{array}{c}69 \\
(55-81)\end{array}$ \\
\hline Grass hays & 38 & $\begin{array}{c}11.3 \\
(4.8-21.0)\end{array}$ & $\begin{array}{c}31.6 \\
(20.3-39.1)\end{array}$ & $\begin{array}{c}52 \\
(37-76)\end{array}$ & $\begin{array}{c}59 \\
(49-73)\end{array}$ \\
\hline Green lucernes & 5 & $\begin{array}{c}19.1 \\
(15.2-25.3)\end{array}$ & $\begin{array}{c}23.6 \\
(19.4-29.3)\end{array}$ & $\begin{array}{c}68 \\
(58-75)\end{array}$ & $\begin{array}{c}69 \\
(61-75)\end{array}$ \\
\hline Lucerne hays & 12 & $\begin{array}{c}17.9 \\
(13.5-21.0)\end{array}$ & $\begin{array}{c}30.4 \\
(25.2-37.6)\end{array}$ & $\begin{array}{c}63 \\
(54-69)\end{array}$ & $\begin{array}{c}60 \\
(54-64)\end{array}$ \\
\hline
\end{tabular}

Extreme values in brackets. 
pre-warmed at $39^{\circ} \mathrm{C}$ and their pistons lubricated with vaseline to prevent gas from escaping, were then inoculated with $30 \mathrm{~mL}$ inoculum under continuous $\mathrm{CO}_{2}$ reflux. They were incubated in a water bath at $39{ }^{\circ} \mathrm{C}$ for 96 hours and gently shaken for half an hour after inoculation, every hour for the first 3 hours and then at each recording time. The gas production (GP) of each syringe was recorded after $3,6,12,24,48,72$ and 96 hours of fermentation. To prevent the gas volume in the syringes from exceeding $60 \mathrm{~mL}$, the pistons were moved back to the $35 \mathrm{~mL}$ position after 12 hours of fermentation. Each substrate was incubated in duplicate in three different runs in order to generate 6 measurements per substrate sample. Each run included in triplicate, a standard sample (the hay fed the fistulated donor animals) and a blank (syringes incubated with the inoculum alone).

\subsubsection{End-products}

After 96 hours of incubation, the medium of each syringe was checked for $\mathrm{pH}$. For 1 of the 3 runs, the residues were then mixed with 0.1 vol. $\mathrm{H}_{3} \mathrm{PO}_{4} 5 \%(\mathrm{v} / \mathrm{v})$ and stored at $-20{ }^{\circ} \mathrm{C}$ for further $\mathrm{NH} 3-\mathrm{N}$ and volatile fatty acid (VFA) analyses. VFA of blanks were subtracted from the measured VFA of samples to obtain VFA production of each substrate. The NH3-N concentration in the medium at the end of fermentation was determined in order to check if medium conditions were correct for normal microbial growth.

\subsubsection{Gas production and data calculation}

Mean gas production data of blanks were subtracted from the recorded gas production of the standard and of all the substrates to get the net gas production values (NGP). NGP of substrates were kept as such after having checked that the SD of standard NGP samples (representing variability between runs) were not higher than $1.5 \mathrm{~mL}$. When this was not the case (which occurred only with 2 runs out of a total of 18 runs), the data of such runs were discarded and not corrected for the standard values. The NGP were then related to a sample weight of exactly $200 \mathrm{mg}$ dry matter.

These calculated GP were fitted with the monomolecular model $\mathrm{y}=\mathrm{a}+\mathrm{b}\left(1-\mathrm{e}^{-\mathrm{ct}}\right)$ of Ørskov and McDonald [29], considering 3, $6,12,24,48,72$ and 96 hours fermentation for all the samples where "a" is the gas produced from the readily fermented organic matter (OM) fraction, " $b$ " the gas produced from the slowly fermented OM fraction and " $c$ " the rate of fermentation of $\mathrm{OM}$; " $(a+b)$ " represents the potential gas production from the total degraded OM of the samples. For the 45 samples of known DMI, the model was also fitted omitting the $96 \mathrm{~h}$ point to check whether it was possible, with such forages, to save time without losing accuracy in prediction.

\subsection{Chemical analysis and other tests}

Ash content was determined after incineration for 6 hours at $550{ }^{\circ} \mathrm{C}$. For all substrates, dry matter (DM), organic matter $(\mathrm{OM})$ and crude protein $(\mathrm{CP})$ content $(6.25 \times$ Kjeldahl nitrogen) were determined by AOAC methods [4]. Crude fibre (CF) was determined by the method of Weende (AFNOR [1]). The degradability of DM in the pepsin-cellulase method (Cellulase) was achieved according to the method of Aufrère and Michalet-Doreau [6]. VFA were determined as described by Jouany[22]. NH3-N was determined as described by Davies and Taylor [15].

\subsection{Statistical analysis}

The effects of experimental factors like botanical family (grass or lucerne), conservation (green or hay) and their interaction on the fermentation characteristics $\left(\mathrm{pH}, \mathrm{NH}_{3}\right.$, VFA, GP) were investigated by analysis of variance of unbalanced design. The linear 
model used was $Y_{i j k}=\mu+\alpha_{i}+\beta_{j}+\gamma_{i j}+\varepsilon_{i j k}$ where $Y_{i j k}, \mu, \alpha_{i}, \beta_{j}, \gamma_{i j}$ and $\varepsilon_{i j k}$ represent respectively the studied variable, intercept, effect (grass or lucerne), effect (green or hay), interaction and independent errors. Parameters of the model were estimated with contrasts of sum and the sums of squares of type III were used to calculate the statistical F.

Regressions between OMD, DMI and DOMI parameters were classified for different forages (grasses or legumes, green or hay). The prediction of these parameters was compared using $\mathrm{CP}, \mathrm{CF}$, Cellulase, the GP at each of the seven fermentation times, and also with linear determinants " $(a+b)$ " and "c". The linear model used was $Y=\alpha+\beta X$ $+\varepsilon$, where $Y, \alpha, \beta, X$ and $\varepsilon$ are respectively explained variables, intercept, slope, regressor and independent error. These predictors were considered either alone or in combination with $\mathrm{CP}$ as an additional explanatory variable. The parameters " $(a+b)$ " and "c" were considered alone in single correlation and in combination in multiple correlation. The parameters "a" and "b" were always considered together " $(a+b)$ ", representing the potential gas production of the sample. The association between dependent and independent variables was expressed as the variance of the model as a percentage of total variance $\left(R^{2}\right)$ and the accuracy of the prediction in terms of its residual standard deviation (RSD).

\section{RESULTS}

\subsection{Fermentation characteristics}

The mean $\mathrm{pH}$ values of rumen liquor were $6.42 \pm 0.12$. The mean $\mathrm{pH}$ value of the blank prior and after incubation did not change and was about $6.89 \pm 0.1$. The average $\mathrm{pH}$ of the medium after $96 \mathrm{~h}$ of fermentation (Tab. II) was, for all the forages, $6.74 \pm 0.05$, which was slightly lower than that (6.89) of the blank at the end of incubation. Both $\mathrm{G}$ and $\mathrm{H}$ lucernes, had a significantly $(P<0.001)$ higher $\mathrm{pH}(6.82 \pm 0.06$ and $6.79 \pm 0.04$ respectively) than both $\mathrm{G}$ and $\mathrm{H}$ grasses $(6.73 \pm 0.06$ and $6.72 \pm 0.04$ respectively) . But there was no statistical effect of forage conservation.

The NH3-N concentration after $96 \mathrm{~h}$ was $353 \pm 58 \mathrm{mg} \cdot \mathrm{L}^{-1}$ on average and, ranged from $311 \mathrm{mg} \cdot \mathrm{L}^{-1}$ on average for the $\mathrm{G}$ lucerne to $386 \mathrm{mg} \cdot \mathrm{L}^{-1}$ on average for the $\mathrm{H}$ lucerne (Tab. II). Conservation of forages had a significant effect $(P<0.05)$ with higher values for hays in the case of lucerne but not grasses (conservation $\times$ botanical family interaction).

Total VFA production was, on average for all forages, $35.10 \pm 6.16 \mathrm{mmoles} \cdot \mathrm{g}^{-1}$ DM (Tab. II). It ranged from 31.50 to 38.18 respectively for $\mathrm{H}$ and $\mathrm{G}$ lucernes and reflected the $\mathrm{pH}$ values except for the $\mathrm{H}$ lucerne.

There was no effect of the botanical family on the molar proportion of VFAs but there was a small effect of conservation, which was significant $(P<0.05)$ for propionate $\left(\mathrm{C}_{3}\right)$ and isobutyrate $\left(\mathrm{iC}_{4}\right)$. The green forages produced slightly higher levels of acetate $\left(\mathrm{C}_{2}\right)$ and $\mathrm{iC}_{4}$ and slightly lower levels of $\mathrm{C}_{3}$ than the hays. The mean $\mathrm{C}_{2}$ proportion (Tab. II) was $66.06 \pm 4.60 \%$. It ranged from $64.10 \pm 7.63$ to $67.40 \pm 1.55 \%$ respectively for the $\mathrm{H}$ lucerne and $\mathrm{G}$ grass. The mean $\mathrm{C}_{3}$ proportion was $22.80 \pm 3.84 \%$ and ranged from $21.02 \pm 1.02$ to $24.12 \pm$ $5.97 \%$ respectively for $\mathrm{G}$ lucerne and $\mathrm{H}$ lucerne $(P<0.05)$. The butyrate $\left(\mathrm{C}_{4}\right)$ proportion (7.31 \pm 1.13 in average) ranged from $6.61 \pm 1.36$ to $7.64 \pm 1.32 \%$ for respectively $\mathrm{H}$ lucerne and $\mathrm{H}$ grass which were not significantly different. The $\mathrm{iC}_{4}$ proportion $(0.62$ $\pm 1.36 \%$ in average) ranged from $0.14 \pm$ 1.30 to $1.60 \pm 0.31$ for respectively $\mathrm{H}$ grass and $\mathrm{G}$ lucerne which were significantly $(P<0.05)$ different.

The parameters of the model were very significantly $(P<0.001)$ influenced by the botanical family. Grasses had a higher " $(\mathrm{a}+\mathrm{b})$ " about $274 \pm 17 \mathrm{~mL} \cdot \mathrm{g}^{-1} \mathrm{DM}$ in contrast with $231.2 \pm 11 \mathrm{~mL} \cdot \mathrm{g}^{-1} \mathrm{DM}$ for 
Table II. Fermentation characteristics ( $\mathrm{pH}, \mathrm{NH} 3$ Nitrogen, total acidity, VFA proportion) of residues after $96 \mathrm{~h}$ of fermentation and gas production profiles observed for the 16 series carried out with the 79 forage samples, considered either together or by categories.

\begin{tabular}{|c|c|c|c|c|c|c|c|c|c|c|c|}
\hline \multirow[t]{2}{*}{ Units } & & \multirow[t]{2}{*}{$n$} & & \multirow{2}{*}{$\begin{array}{l}\mathrm{NH} 3-\mathrm{N} \\
\mathrm{mg} \cdot \mathrm{L}^{-1}\end{array}$} & \multirow{2}{*}{$\begin{array}{c}\text { Total acidity } \\
\mathrm{mmol} \cdot \mathrm{g}^{-1} \\
\mathrm{DM}\end{array}$} & \multirow[t]{2}{*}{${ }^{1} \mathrm{C} 2$} & ${ }^{2} \mathrm{C} 3$ & ${ }^{3} \mathrm{C} 4$ & ${ }^{4} \mathrm{IC} 4$ & \multirow{2}{*}{$\begin{array}{l}5(a+b) \\
m L \cdot g^{-1}\end{array}$} & \multirow{2}{*}{$\begin{array}{l}{ }^{6} \mathrm{c} \\
\mathrm{h}^{-1}\end{array}$} \\
\hline & & & & & & & \multicolumn{2}{|c|}{$\%$} & & & \\
\hline All substrates & & 79 & & & & & & & & & \\
\hline Mean & & & 6.74 & 353 & 35.10 & 66.06 & 22.80 & 7.31 & 0.62 & 265.0 & 0.067 \\
\hline & SD & & 0.05 & 58 & 6.16 & 4.60 & 3.84 & 1.13 & 1.36 & 16.5 & 0.012 \\
\hline Green grasses & & 24 & & & & & & & & & \\
\hline Mean & & & $6.73^{\mathrm{a}}$ & $354^{\mathrm{ab}}$ & $36.21^{\mathrm{a}}$ & 67.40 & $21.33^{\mathrm{a}}$ & 7.15 & $1.02^{\mathrm{a}}$ & $270.0^{\mathrm{a}}$ & $0.067^{\mathrm{a}}$ \\
\hline & SD & & 0.06 & 46 & 5.38 & 1.55 & 3.17 & 0.62 & 1.41 & 21.5 & 0.012 \\
\hline Grass hays & & 38 & & & & & & & & & \\
\hline Mean & & & $6.72^{\mathrm{a}}$ & $348^{\mathrm{a}}$ & $35.13^{\mathrm{ab}}$ & 65.87 & $23.55^{\mathrm{b}}$ & 7.64 & $0.14^{\mathrm{b}}$ & $277.0^{\mathrm{a}}$ & $0.054^{\mathrm{b}}$ \\
\hline & SD & & 0.04 & 64 & 7.23 & 4.90 & 3.59 & 1.32 & 1.30 & 14.5 & 0.011 \\
\hline Green lucernes & & 5 & & & & & & & & & \\
\hline Mean & & & $6.82^{\mathrm{b}}$ & $311^{\mathrm{a}}$ & $38.18^{\mathrm{a}}$ & 65.66 & $21.02^{\mathrm{ab}}$ & 7.16 & $1.60^{\mathrm{a}}$ & $242.5^{\mathrm{b}}$ & $0.093^{\mathrm{c}}$ \\
\hline & SD & & 0.06 & 62 & 3.45 & 0.56 & 1.02 & 0.76 & 0.31 & 12.0 & 0.016 \\
\hline Lucerne hays & & 12 & & & & & & & & & \\
\hline Mean & & & $6.79^{\mathrm{b}}$ & 386 & $31.50^{\mathrm{b}}$ & 64.10 & $24.12^{\mathrm{b}}$ & 6.61 & $0.92^{\mathrm{ab}}$ & $226.5^{\mathrm{b}}$ & $0.090^{\mathrm{c}}$ \\
\hline & SD & & 0.04 & 61 & 4.19 & 7.63 & 5.97 & 1.36 & 1.65 & 10.0 & 0.010 \\
\hline Green $(\mathrm{G})$ or Hay $(\mathrm{H})$ & & & ns & $*$ & $*$ & $\mathrm{~ns}$ & $*$ & $\mathrm{~ns}$ & $*$ & ns & $* *$ \\
\hline Grass (g) or lucerne (1) & & & $* * *$ & ns & ns & $\mathrm{ns}$ & ns & ns & ns & $* * *$ & $* * *$ \\
\hline$(\mathrm{G}$ or $\mathrm{H}) \times(\mathrm{g}$ or $\mathrm{l})$ & & & $\mathrm{ns}$ & $*$ & ns & ns & $\mathrm{ns}$ & ns & $\mathrm{ns}$ & $\mathrm{ns}$ & $*$ \\
\hline
\end{tabular}

${ }^{1}$ Acetic acid, ${ }^{2}$ propionic acid, ${ }^{3}$ butyric acid, ${ }^{4}$ isobutyric acid, ${ }^{5}$ potential gas production, ${ }^{6}$ rate of gas production. Data bearing the same superscript within a column are not different at $P<0.05$.

Data bearing the same superscript within a column are not different at $P<0.05$.
Effects: ns = not significant; $* *=$ significant at $P<0.05 ; * * *=$ significant at $P<0.001$. 
lucerne. Conversely, the gas production rate " $\mathrm{c}$ " was higher for lucerne $0.091 \pm 0.011 \cdot \mathrm{h}^{-1}$ $(P<0.001)$ and was significantly $(P<0.01)$ influenced by conservation for grasses only: $0.067 \pm 0.012$ and $0.054 \pm 0.011 \cdot \mathrm{h}^{-1}$ for respectively $\mathrm{G}$ and $\mathrm{H}$ grasses (Tab. II).

\subsection{OMD prediction}

\subsubsection{Six or seven recording times for the Ørskov model}

Seven recording times (including $96 \mathrm{~h}$ ) tested on the 45 forages with known intake, did not allow a significantly better prediction accuracy of OMD than 6 recording times (omitting $96 \mathrm{~h}$ ). RSD was, respectively for 7 and 6 recording times, 7.91 and 7.66 with the " $(\mathrm{a}+\mathrm{b})$ " values and 6.25 and 6.41 with the "c" values of the model. It is also worth noting that "c" (rate of fermentation) was surprisingly better than " $(a+b)$ " (potential degradability) in predicting OMD. Since it was much less time consuming, it is advisable to use 6 checking times for 72 hours. Nevertheless we used 7 checking times in the rest of the study in order to avoid any risks of errors linked with either eventual uncompleted fermentation or eventual bias implied by the mathematical fitting of the curves.

\subsubsection{Considering forages by categories}

The high effect of the botanical family and conservation on the gas production profiles (Tab. II) led us to separate the forages into four separate categories, $\mathrm{G}$ and $\mathrm{H}$ grasses and $\mathrm{G}$ and $\mathrm{H}$ lucernes, for the calculation of the correlation between OMD (and DMI and DOMI) and the various predictors. In fact, from Figure 1 where OMD is plotted against "c", it was clear that G and $\mathrm{H}$ grasses and $\mathrm{G}$ and $\mathrm{H}$ lucernes belong to different populations. Tables III and IV regroup $R^{2}$ and RSD values of the correlations with the most explanatory variables.

\subsubsection{Accuracy of prediction}

The best prediction of G grass OMD was obtained with Cellulase alone with an RSD of 1.86 (Tab. III). The best RSD allowed by the gas fermentation characteristics were obtained with the parameters of the model $([(a+b), c], R S D=2.11)$, which remained inferior to those allowed by Cellulase. Figure 1 shows that the degradation rate (c) also allowed a good accuracy of prediction (RSD of 2.16). Addition of CP significantly improved the prediction accuracy obtained with GP at $12 \mathrm{~h}$ or $24 \mathrm{~h}$ but not that obtained with "c" or Cellulase $(\mathrm{RSD}=1.90)$.

The best prediction of $\mathrm{H}$ grass OMD was obtained with the parameters of the model $[(\mathrm{a}+\mathrm{b}), \mathrm{c}],(\mathrm{RSD}=2.39)$. Cellulase permitted an RSD of 2.67, slightly inferior to that allowed by GP $24 \mathrm{~h}$ (2.61). Addition of CP significantly improved the prediction accuracy obtained with GP $24 \mathrm{~h}(\mathrm{RSD}=$ $2.24)$ or with $[(a+b), c](R S D=2.10)$.

Figure 1 shows that, (1) more obviously than in the case of grasses, G lucerne, although there were only 5 samples, belong to a different population than $\mathrm{H}$ lucerne and, (2) they were better predicted than $\mathrm{H}$ lucerne.

The best prediction was obtained with Cellulase for $\mathrm{G}$ and $\mathrm{H}$ lucernes $(\mathrm{RSD}=1.75$ and 2.02 respectively). The best predictions from the GP characteristics were the rate (c) for the G Lucerne (RSD = 0.88) and GP $24 \mathrm{~h}$ for the H lucerne (RSD = 2.40). Prediction accuracy (RSD) was improved by adding the $\mathrm{CP}$ content for the $\mathrm{G}$ lucerne only.

\subsection{DMI prediction (Tab. IV, Fig. 2)}

The prediction of G grass DMI was fair with the GP parameters and Cellulase. The best prediction was obtained with $\mathrm{CP}$ alone $(\mathrm{RSD}=7.50)$. The best prediction of $\mathrm{H}$ grass was obtained with Cellulase $(\mathrm{RSD}=6.37)$ followed by the "c" parameter $(\mathrm{RSD}=6.88)$. Adding CP did not improve the accuracy of the prediction. 


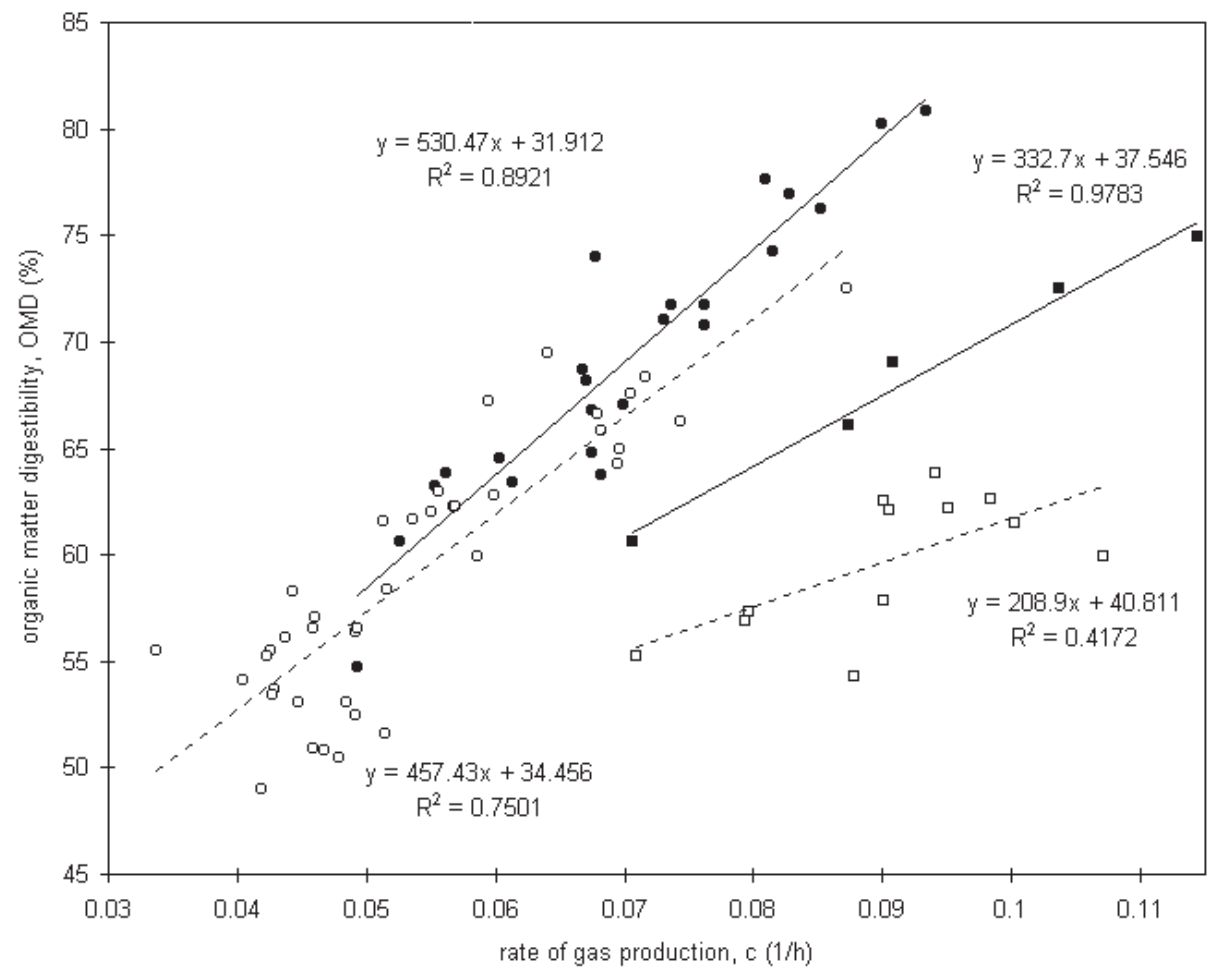

Figure 1. Relationships between in vivo OMD of 79 pasture plants and c value of the cumulative in vitro gas production according to botanical family and conditioning of the plants.

(๑) Green grasses; (○) grass hays; $(\square)$ green lucernes; $(\square)$ lucerne hays.

Table III. Precision (RSD) of the prediction of organic matter digestibility (OMD) of forages from Cellulase and crude protein content and gas production characteristics alone or in combination with one another.

\begin{tabular}{|c|c|c|c|c|c|c|c|}
\hline \multicolumn{3}{|c|}{ Predictor $^{1}$} & \multirow[b]{2}{*}{$R^{2}$} & \multirow[b]{2}{*}{ RSD } & \multicolumn{3}{|c|}{ Significance of predictor ${ }^{2}$} \\
\hline $1 \mathrm{st}$ & 2nd & 3 rd & & & $1 \mathrm{st}$ & 2nd & 3 rd \\
\hline \multicolumn{8}{|c|}{ Green grasses, $n=24,(54.7-80.8)$} \\
\hline $\mathrm{CP}$ & & & 0.31 & 5.65 & $* *$ & & \\
\hline cellulase & & & 0.93 & 1.86 & $* * *$ & & \\
\hline $12 \mathrm{~h}$ & & & 0.66 & 3.96 & $* * *$ & & \\
\hline $24 \mathrm{~h}$ & & & 0.59 & 4.32 & $* * *$ & & \\
\hline c & & & 0.90 & 2.16 & $* * *$ & & \\
\hline$(a+b)$ & & & 0.15 & 6.25 & ns & & \\
\hline$(a+b)$ & $\mathrm{c}$ & & 0.91 & 2.11 & ns & $* * *$ & \\
\hline cellulase & $\mathrm{CP}$ & & 0.93 & 1.90 & $* * *$ & $\mathrm{~ns}$ & \\
\hline $12 \mathrm{~h}$ & $\mathrm{CP}$ & & 0.79 & 3.17 & $* * *$ & $* *$ & \\
\hline $24 \mathrm{~h}$ & $\mathrm{CP}$ & & 0.78 & 3.26 & $* * *$ & $* * *$ & \\
\hline c & $\mathrm{CP}$ & & 0.90 & 2.21 & $* * *$ & $\mathrm{~ns}$ & \\
\hline$(a+b)$ & $\mathrm{c}$ & $\mathrm{CP}$ & 0.91 & 2.16 & $\mathrm{~ns}$ & $* * *$ & ns \\
\hline
\end{tabular}


Table III. (Continued).

\begin{tabular}{|c|c|c|c|c|c|c|c|}
\hline \multicolumn{3}{|c|}{ Predictor $^{1}$} & \multirow[b]{2}{*}{$R^{2}$} & \multirow[b]{2}{*}{ RSD } & \multicolumn{3}{|c|}{ Significance of predictor ${ }^{2}$} \\
\hline $1 \mathrm{st}$ & 2nd & $3 \mathrm{rd}$ & & & $1 \mathrm{st}$ & 2nd & $3 r d$ \\
\hline \multicolumn{8}{|c|}{ Grass hays, $n=38,(49.0-72.5)$} \\
\hline $\mathrm{CP}$ & & & 0.56 & 4.19 & $* * *$ & & \\
\hline cellulase & & & 0.82 & 2.67 & $* * *$ & & \\
\hline $12 \mathrm{~h}$ & & & 0.70 & 3.43 & $* * *$ & & \\
\hline $24 \mathrm{~h}$ & & & 0.83 & 2.61 & $* * *$ & & \\
\hline $\mathrm{c}$ & & & 0.76 & 3.12 & $* * *$ & & \\
\hline$(a+b)$ & & & 0.28 & 5.34 & $* * *$ & & \\
\hline$(a+b)$ & $\mathrm{c}$ & & 0.86 & 2.39 & $* * *$ & $* * *$ & \\
\hline cellulase & $\mathrm{CP}$ & & 0.83 & 2.64 & $* * *$ & ns & \\
\hline $12 \mathrm{~h}$ & $\mathrm{CP}$ & & 0.80 & 2.87 & $* * *$ & $* * *$ & \\
\hline $24 \mathrm{~h}$ & $\mathrm{CP}$ & & 0.88 & 2.24 & $* * *$ & $* * *$ & \\
\hline $\mathrm{c}$ & $\mathrm{CP}$ & & 0.79 & 2.91 & $* * *$ & $*$ & \\
\hline$(a+b)$ & $\mathrm{c}$ & $\mathrm{CP}$ & 0.90 & 2.10 & $* * *$ & $* * *$ & $* *$ \\
\hline \multicolumn{8}{|c|}{ Green lucernes, $n=5$, (60.6-74.9) } \\
\hline $\mathrm{CP}$ & & & 0.61 & 4.06 & ns & & \\
\hline cellulase & & & 0.93 & 1.75 & $* *$ & & \\
\hline $6 \mathrm{~h}$ & & & 0.77 & 3.12 & ns & & \\
\hline $12 \mathrm{~h}$ & & & 0.68 & 3.64 & ns & & \\
\hline $24 \mathrm{~h}$ & & & 0.22 & 5.70 & ns & & \\
\hline $\mathrm{c}$ & & & 0.98 & 0.88 & $* *$ & & \\
\hline$(a+b)$ & & & 0.16 & 5.93 & ns & & \\
\hline$(a+b)$ & $\mathrm{c}$ & & 0.98 & 1.00 & ns & $* *$ & \\
\hline cellulase & $\mathrm{CP}$ & & 1.00 & 0.55 & $* *$ & $*$ & \\
\hline $6 \mathrm{~h}$ & $\mathrm{CP}$ & & 0.99 & 0.79 & $*$ & $*$ & \\
\hline \multicolumn{8}{|c|}{ Lucerne hays, $n=12,(54.3-63.8)$} \\
\hline $\mathrm{CP}$ & & & 0.14 & 3.14 & ns & & \\
\hline cellulase & & & 0.65 & 2.02 & $* *$ & & \\
\hline $12 \mathrm{~h}$ & & & 0.44 & 2.55 & $*$ & & \\
\hline $24 \mathrm{~h}$ & & & 0.50 & 2.40 & $*$ & & \\
\hline $\mathrm{c}$ & & & 0.41 & 2.61 & $*$ & & \\
\hline$(a+b)$ & & & 0.37 & 2.70 & $*$ & & \\
\hline$(a+b)$ & $\mathrm{c}$ & & 0.52 & 2.47 & ns & ns & \\
\hline cellulase & $\mathrm{CP}$ & & 0.65 & 2.13 & $* *$ & ns & \\
\hline $12 \mathrm{~h}$ & $\mathrm{CP}$ & & 0.51 & 2.50 & $*$ & ns & \\
\hline $24 \mathrm{~h}$ & $\mathrm{CP}$ & & 0.59 & 2.28 & $*$ & ns & \\
\hline $\mathrm{c}$ & $\mathrm{CP}$ & & 0.43 & 2.69 & ns & ns & \\
\hline$(a+b)$ & $\mathrm{c}$ & $\mathrm{CP}$ & 0.59 & 2.43 & ns & ns & \\
\hline
\end{tabular}

${ }^{1} \mathrm{CP}$ : crude protein; $\mathrm{CF}$ : crude fibre; Cellulase: pepsin-cellulase method.

$(a+b)$ : potential gas production, $c$ : rate of gas production of the model $y=a+b\left(1-e^{(-c t)}\right)$.

$12 \mathrm{~h}$ and $24 \mathrm{~h}$ are the quantities of gas produced after, respectively 12 and 24 hours incubation.

${ }^{2}$ Effects: ns $=$ not significant; $* *=$ significant at $P<0.05 ; * * *=$ significant at $P<0.001$. 
Table IV. Precision (RSD) of the prediction of voluntary dry matter intake (DMI) and digestible organic matter intake (DOMI) of forages from Cellulase and crude protein content and gas production characteristics alone or in combination with one another.

\begin{tabular}{|c|c|c|c|c|c|c|c|}
\hline \multicolumn{3}{|c|}{ Predictor $^{1}$} & \multirow[b]{2}{*}{$R^{2}$} & \multirow[b]{2}{*}{ RSD } & \multicolumn{3}{|c|}{ Significance of predictor ${ }^{2}$} \\
\hline $1 \mathrm{st}$ & 2nd & $3 \mathrm{rd}$ & & & $1 \mathrm{st}$ & $2 \mathrm{nd}$ & $3 \mathrm{rd}$ \\
\hline
\end{tabular}

\section{DMI (g.L $\left.\mathbf{W}^{-0.75}\right)$ prediction}

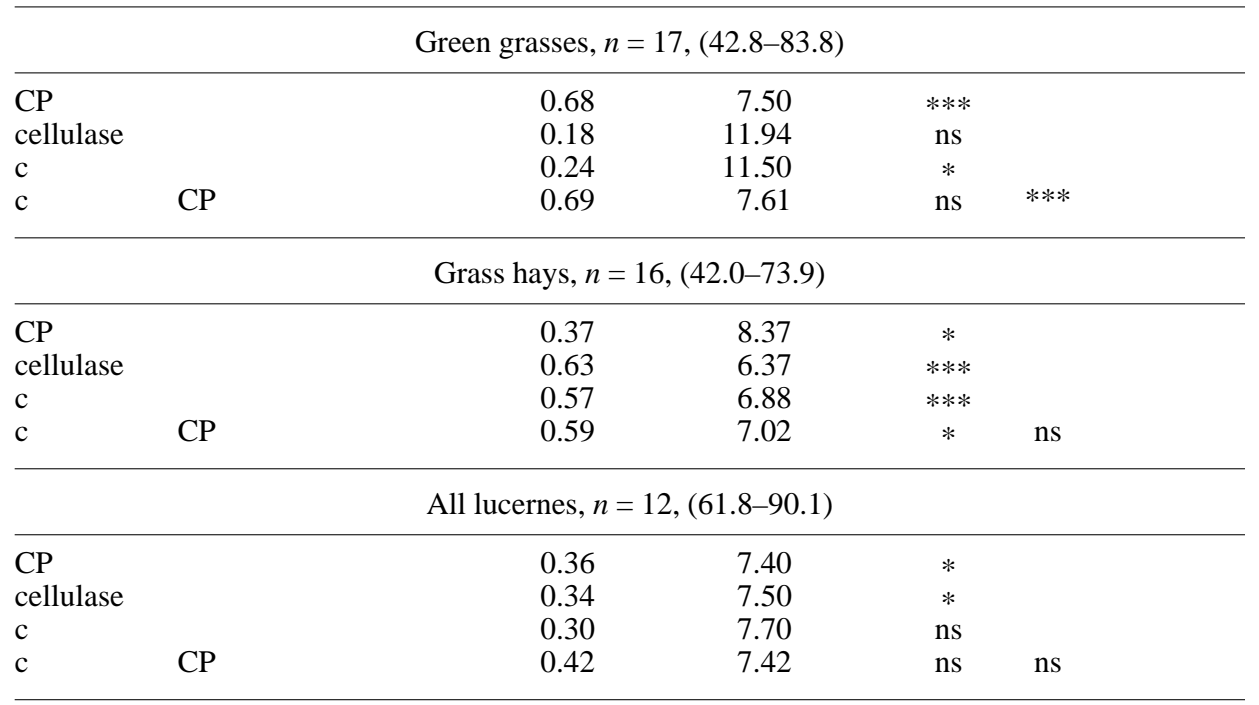

\section{DOMI $\left(g \cdot \mathbf{L} \mathbf{W}^{-0.75}\right)$ prediction}

Green grasses, $n=17,(26.7-57.2)$

\begin{tabular}{|c|c|c|c|c|c|c|c|}
\hline $\mathrm{CP}$ & & & 0.80 & 4.98 & $* * *$ & & \\
\hline $\mathrm{CF}$ & & & 0.65 & 6.68 & $* * *$ & & \\
\hline cellulase & & & 0.54 & 7.64 & $* * *$ & & \\
\hline $24 \mathrm{~h}$ & & & 0.09 & 10.69 & ns & & \\
\hline $\mathrm{c}$ & & & 0.62 & 6.96 & $* * *$ & & \\
\hline$(a+b)$ & $\mathrm{c}$ & & 0.77 & 5.57 & $* *$ & $* * *$ & \\
\hline $\mathrm{CF}$ & $\mathrm{CP}$ & & 0.85 & 4.52 & ns & $* * *$ & \\
\hline Cellulase & $\mathrm{CP}$ & & 0.84 & 4.59 & ns & $* * *$ & \\
\hline $\mathrm{C}$ & $\mathrm{CP}$ & & 0.85 & 4.47 & $*$ & $* * *$ & \\
\hline$(a+b)$ & $\mathrm{c}$ & $\mathrm{CP}$ & 0.86 & 4.57 & ns & ns & $*$ \\
\hline \multicolumn{8}{|c|}{ Grass hays, $n=16,(21.4-52.5)$} \\
\hline $\mathrm{CP}$ & & & 0.54 & 6.50 & $* *$ & & \\
\hline $\mathrm{CF}$ & & & 0.78 & 4.55 & $* * *$ & & \\
\hline Cellulase & & & 0.86 & 3.67 & $* * *$ & & \\
\hline $24 \mathrm{~h}$ & & & 0.64 & 5.77 & $* * *$ & & \\
\hline $\mathrm{C}$ & & & 0.76 & 4.77 & $* * *$ & & \\
\hline$(a+b)$ & $\mathrm{c}$ & & 0.76 & 4.90 & ns & $* * *$ & \\
\hline $\mathrm{CF}$ & $\mathrm{CP}$ & & 0.81 & 4.41 & $* *$ & ns & \\
\hline Cellulase & $\mathrm{CP}$ & & 0.86 & 3.81 & $* * *$ & ns & \\
\hline
\end{tabular}


Table IV. (Continued).

\begin{tabular}{|c|c|c|c|c|c|c|c|}
\hline \multicolumn{3}{|c|}{ Predictor $^{1}$} & \multirow[b]{2}{*}{$R^{2}$} & \multirow[b]{2}{*}{ RSD } & \multicolumn{3}{|c|}{ Significance of predictor ${ }^{2}$} \\
\hline $1 \mathrm{st}$ & 2nd & 3rd & & & $1 \mathrm{st}$ & 2nd & 3rd \\
\hline $\mathrm{C}$ & $\mathrm{CP}$ & & 0.79 & 4.55 & $* *$ & ns & \\
\hline$(a+b)$ & $\mathrm{c}$ & $\mathrm{CP}$ & 0.79 & 4.73 & ns & $* *$ & ns \\
\hline \multicolumn{8}{|c|}{ All lucernes, $n=12$, (35.4-63.9) } \\
\hline $\mathrm{CP}$ & & & 0.54 & 5.90 & $* *$ & & \\
\hline $\mathrm{CF}$ & & & 0.84 & 3.50 & $* * *$ & & \\
\hline Cellulase & & & 0.74 & 4.43 & $* * *$ & & \\
\hline $12 \mathrm{~h}$ & & & 0.59 & 5.60 & $* *$ & & \\
\hline $24 \mathrm{~h}$ & & & 0.46 & 6.40 & $*$ & & \\
\hline $\mathrm{c}$ & & & 0.71 & 4.70 & $* * *$ & & \\
\hline$(a+b)$ & $\mathrm{c}$ & & 0.75 & 4.60 & $* *$ & ns & \\
\hline $\mathrm{CF}$ & $\mathrm{CP}$ & & 0.87 & 3.37 & $* *$ & ns & \\
\hline Cellulase & $\mathrm{CP}$ & & 0.85 & 3.50 & $* *$ & $*$ & \\
\hline $\mathrm{C}$ & $\mathrm{CP}$ & & 0.80 & 4.10 & $* *$ & ns & \\
\hline $12 \mathrm{~h}$ & $\mathrm{CP}$ & & 0.95 & 1.96 & $* * *$ & $* * *$ & \\
\hline
\end{tabular}

${ }^{1} \mathrm{CP}$ : crude protein; $\mathrm{CF}$ : crude fibre; Cellulase: pepsin-cellulase method.

$(a+b)$ : potential gas production, $c$ : rate of gas production of the model $y=a+b\left(1-e^{(-c t)}\right)$.

$12 \mathrm{~h}$ and $24 \mathrm{~h}$ are the quantities of gas produced after, respectively 12 and 24 hours incubation.

${ }^{2}$ Effects: $\mathrm{ns}=$ not significant; $* *=$ significant at $P<0.05 ; * * *=$ significant at $P<0.001$.

Too few lucerne samples did not allow reasonable RSD in the prediction of their DMI. However, pooling all the lucerne (green and hays, $n=12$ ) led CP to an RSD of 7.40. Cellulase gave a similar result (RSD $=7.50$ ) although "c" was not significant.

\subsection{DOMI prediction (Tab. IV)}

Although statistically significant, neither chemical nor gas-test predictors taken alone allowed a reasonable RSD for $\mathrm{G}$ grasses except CP $(\mathrm{RSD}=4.98)$. CP significantly improved $(P<0.001)$ the prediction but only in the case of $\mathrm{G}$ grasses. Combinations of $\mathrm{CP}$ with $\mathrm{CF}$, Cellulase, and "c" led to RSD of, respectively, 4.52, 4.59 and 4.47. For $\mathrm{H}$ grass, the better prediction of DOMI was obtained with Cellulase (RSD = 3.67).

Pooling $\mathrm{G}$ and $\mathrm{H}$ lucernes still allowed correct RSD, the best ones being respectively 4.43 with Cellulase and 1.96 with the $\mathrm{GP} 12 \mathrm{~h} \times \mathrm{CP}$ combination.
According to Figures 1 and 2, it appears that the "c" value allowed better pooling of all categories of forages when plotted against DOMI than against OMD. In fact, regrouping all the 45 samples led Cellulase and "c" $\times \mathrm{CP}$ to an RSD of respectively 5.63 and 5.35 which were not too bad in view of the large range of DOMI variation (21.4 to $\left.69.9 \mathrm{~g} \cdot \mathrm{kg}^{-1} \mathrm{LW} 0.75\right)$. The best predictions were obtained with Cellulase alone for the 16 grass hays $(\mathrm{RSD}=3.67)$ and with GP $12 \mathrm{~h} \times \mathrm{CP}$ for the 12 legumes $(\mathrm{RSD}=1.96)$.

\section{DISCUSSION}

\section{OMD prediction}

Choice of a parameter of gas production technique for $\mathrm{OMD}$ prediction

In our results, the rate of fermentation (c) was always a better predictor of OMD than the potential degradability $(a+b)$. This 


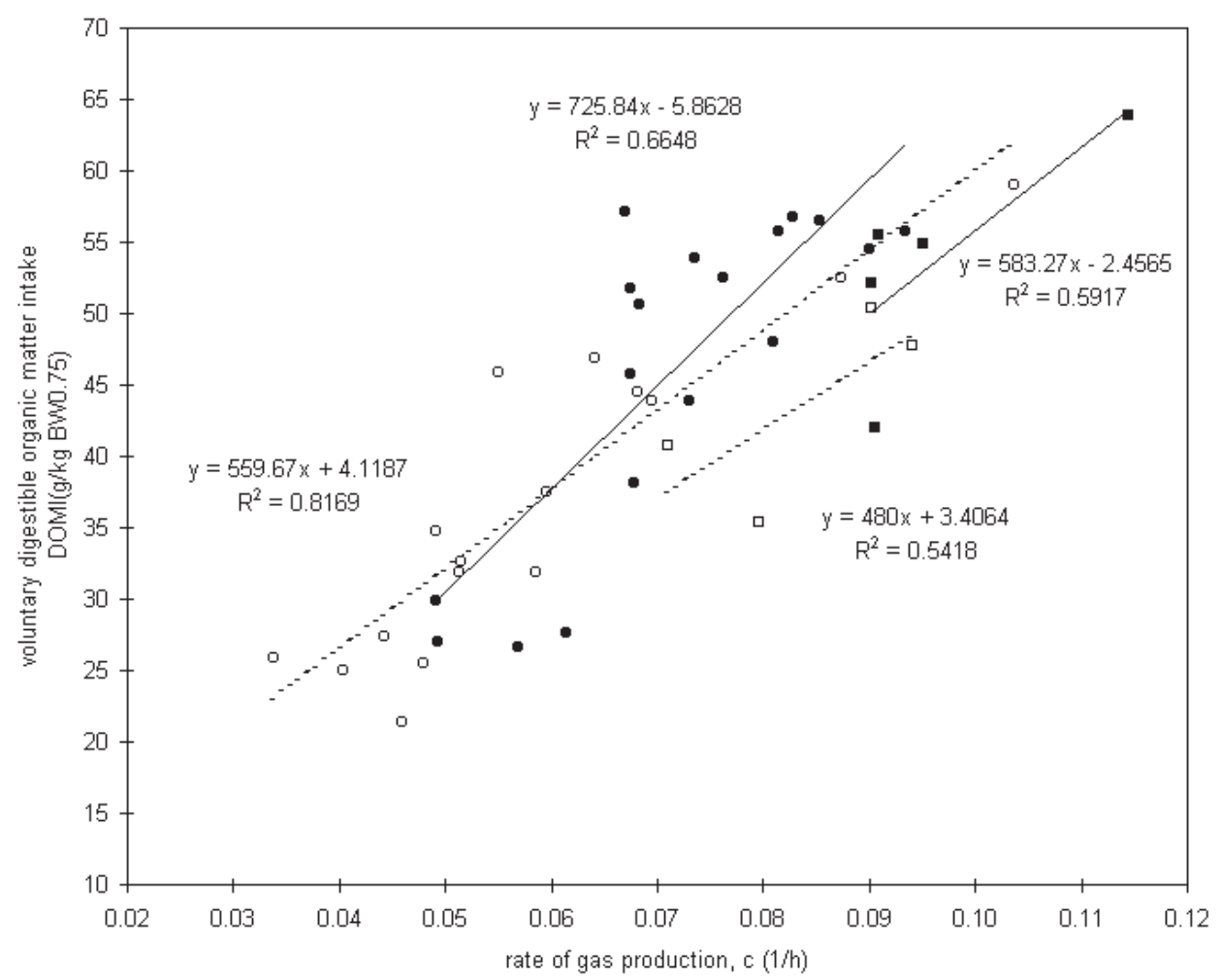

Figure 2. Relationships between voluntary in vivo DOMI of 45 pasture plants and c value of the cumulative in vitro gas production according to the botanical family and conditioning of the plants.

$(\bullet)$ Green grasses; ( $\bigcirc)$ grass hays; $(\square)$ green lucernes; $(\square)$ lucerne hays.

observation is consistent with that recorded with whole plant maize [13], although forages were less rapidly fermented than maize. The best GP recording time for hays (grass and lucerne) was about $24 \mathrm{~h}$ whereas it was about $12 \mathrm{~h}$ for green grasses and $6 \mathrm{~h}$ for green lucerne which contained more soluble, rapidly fermented carbohydrates. In most cases, the model parameters $((a+b), c)$ were more accurate than the recording times but more time was required (till $96 \mathrm{~h}$ ) to correctly fit the GP curve. So, it might be interesting to choose one relevant recording time between $6 \mathrm{~h}$ and $24 \mathrm{~h}$ according to the kind of sample for a faster prediction.

The accuracy of OMD prediction was better with green forages than hays for the more significant predictors (Cellulase, or GP parameters). This might partly be explained by the fact that haymaking with lucerne leads to greater and more variable losses of leaves than with grasses.

The OMD prediction accuracy was not improved by adding the $\mathrm{CP}$ content as a predictor with Cellulase except in the case of green lucerne as we observed previously for maize [3] but not for forages [5]. Conversely, adding $\mathrm{CP}$ content as a predictor of the GP parameters allowed an improvement of the accuracy of the prediction (except with H lucerne), as we found previously [13, 24, 25]. This was likely to be attributed to the mathematically more important "weight" of the inherent direct relationship between $\mathrm{CP}$ 
and digestibility $\left(R^{2}=0.31,0.56,0.61\right.$ and 0.14 , respectively for GG, GH, GL and LH), in the case of a poor correlation such as that between OMD and $(a+b)$ rather than in the case of an already good relationship between OMD and (c). This improvement might also be due, as suggested by Khazaal et al. [23], to the fact that CP may act as a "correction factor" of the bias introduced by the protein fermentation of forages rich in CP such as legumes. One explanation may be that $\mathrm{NH}_{4} \mathrm{HCO}_{3}$ formation from $\mathrm{NH}_{3}$ of $\mathrm{CP}$ fermentation and from $\mathrm{CO}_{2}$ therefore leads to a reduced contribution of $\mathrm{CO}_{2}$ in the total gas produced and $\mathrm{CP}$ produces less gas $\left(\mathrm{CO}_{2}\right)$ than the fermentation of carbohydrates.

With our results, the best prediction of OMD was obtained with Cellulase except for grass hay. These results are in close agreement with those reported by Macheboeuf et al. [24]. In other works [2, 20, 27], the more accurate equations were obtained with GP but they include other parameters of chemical composition. These equations are not useful for routine prediction because they are time consuming.

The relationships between DMI and the gas production values or the parameters of the mathematical model were fair and disappointing as in the results of Romney et al. [30], Sandoval-Castro and Mendoza-Nazar [31] but on the contrary to those of Baumont et al. [7] $\left(R^{2}=0.84 ; \mathrm{RSD}=5.7 ; n=18\right)$.

The accuracy of prediction of DMI was fair with the rate of fermentation "c" which would, a priori, have been expected to work better since it reflects the physical regulation of voluntary intake with ruminants. The former observation supports Blümmel et al.'s findings $[9,11]$ which indicate that the rate of fermentation cannot be considered alone as a predictor for the rate of degradation and therefore of intake - in view of the bias introduced by the synthesis of microbial biomass. The relationships were not really improved by adding CP content as observed by Khazaal et al. [23] except in the case of $\mathrm{G}$ grasses but, in our study due to an already direct good relationship between $\mathrm{CP}$ and intake $\left(R^{2}=0.68\right.$ and 0.74 respectively for Khazaal et al. [23] and Romney et al. [30]).

Various workers [12,19] have reported significant correlations between in vitro gas production and dry matter intake. But gas production from extracted neutral detergent fibre (NDF) was shown to be better correlated to voluntary feed intake than the values obtained from the incubation of whole roughage [8].

The prediction of DMI was similar when based on GP as compared to calculations based on the chemical composition (Dulphy et al. [18], with CP and NDF as predictors; Demarquilly et al. [17] with crude fibre; Baumont et al. [7] with NDF). The accuracy of the relationship between Cellulase or GP and DMI is similar and higher (Baumont et al. [7], RSD about 5).

Since DOMI integrates digestibility and intake, it therefore reflects the global potential feeding value of forages and it is important to predict it with the best accuracy as possible. As a result of the low precision in DMI prediction as compared with that of OMD, the level of prediction of the overall DOMI lays in between those of OMD and DMI. In summary, for DOMI, the most accurate predictor (Tab. IV) for grass hay was Cellulase and, to a lesser extent CP; for the pooled lucerne it was more precise using GP (12 h) and CP. Whereas for the pooled forages, the best predictors were $\mathrm{CP}$ and $\mathrm{c}$ and to a lesser extent, Cellulase.

GP could be an interesting technique but essentially for voluntary DOMI prediction, and this, due rather to DMO than to DMI prediction although one would have expected that the fermentation (i.e. degradation) rate would have been a better predictor of DMI (physical regulation of intake).

\section{CONCLUSION}

Before the GP technique can be adopted as an accurate prediction technique of forage 
nutritive value, several points remain to be clarified:

- to account for the factors influencing VFA synthesis and for the synthesis of microbial biomass in relation to gas production. The latter point was approached through the partitioning factor (PF), as proposed by Blümmel et al. [12], when using the non automated technique with limited measurement points. It was most likely taken into consideration through the multiphasic analysis of gas production kinetics when automated techniques such as those proposed by Cone et al. [14] are available;

- to reduce the work load by reducing the number of recording times and, even, taking only one of them (which should likely differ according to the rate of digestion, and, therefore the botanical family);

- to account for the nature of fermentation $\left(\mathrm{CO}_{2}\right.$ of chemical vs. feed fermentation origin, methane vs. propionate pathway, methanogenesis vs. acetogenesis).

The fair degree of precision of the prediction found could therefore make the GP technique interesting in ranking feedstuffs rather than in assessing their absolute value using NIRS. This was not compared here but has been previously researched for forages (Andrieu, unpublished results), straws [21] and for whole maize plants [3, 13]

It was therefore difficult to discard the Cellulase and GP technique. It was difficult

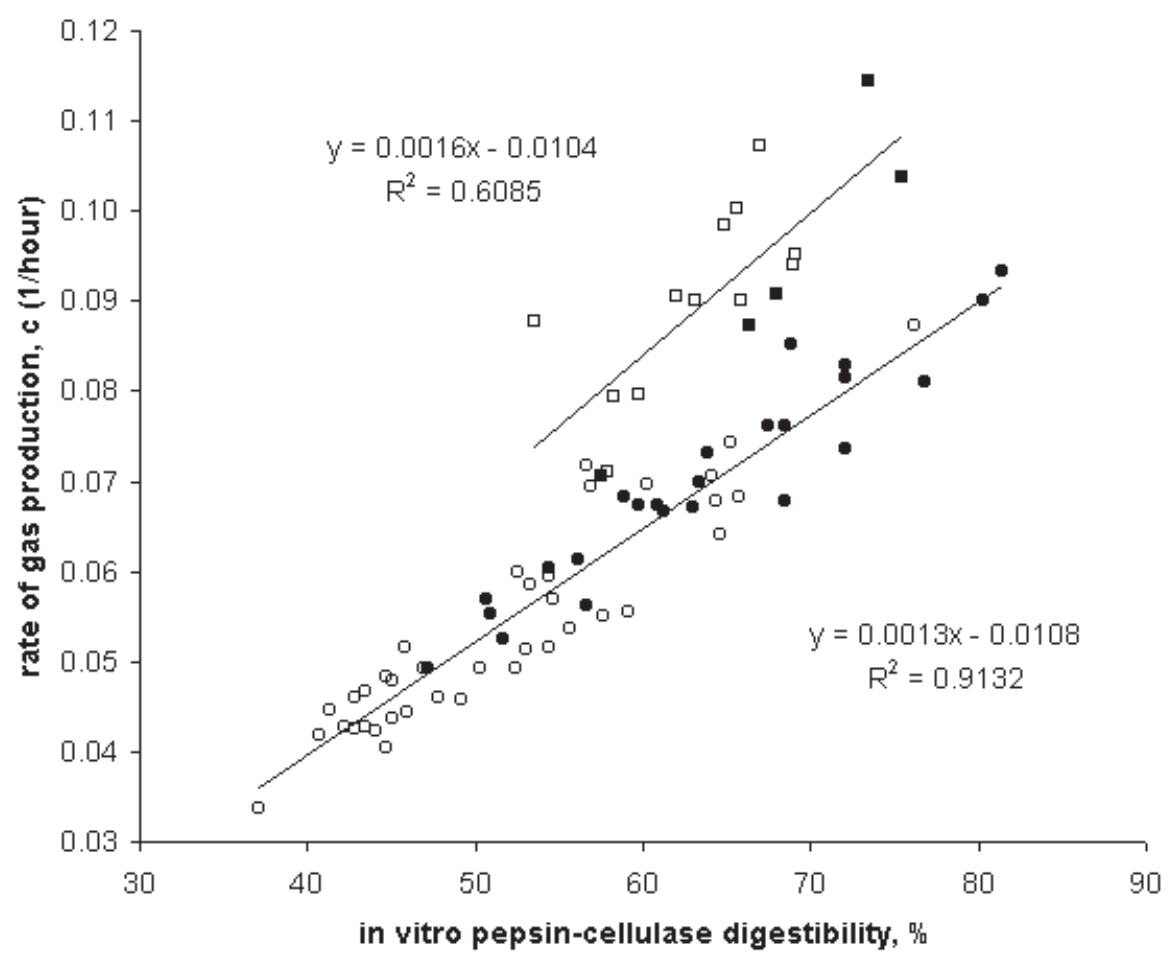

Figure 3. Relationships between pepsin-cellulase method and gas production method results for 79 pasture plants.

(๑) Green grasses; (○) grass hays; $(\square)$ green lucernes; $(\square)$ lucerne hays. 
to choose a universal optimal point of reference using the GP technique, since for some forages it was better to use an individual fermentation time point and for others, the model generated by the relation of several observations. What altogether remains "remarkable" was the fair position of the GP technique as a predictor of the feeding value of forages as compared with $\mathrm{CP}$ and Cellulase, which were simpler, cheaper and less time and skill requiring than the GP technique. Generally, the GP technique gave results which were similar to those of Cellulase for grasses, but not for lucerne (Fig. 3).

In this study, Cellulase was a single, fast and useful method which was as accurate as the GP method.

\section{ACKNOWLEDGMENTS}

The authors thank J. Andrieu, R. Baumont for the loan of the forage samples bank. They also thank Mrs. F. Deverre and B. Lassalas at the URH Laboratory, for the analytical services.

\section{REFERENCES}

[1] AFNOR, Cellulose brute, Méthode CEE $4^{\mathrm{e}}$ directive norme NF 03-040, in: Aliments des animaux, Méthodes d'analyses, Ed. AFNOR 1981.

[2] Aiple K.P., Steingass H., Drochner W., Prediction of the net energy content of raw materials and compounds feeds for ruminants by different laboratory methods, Arch. Anim. Nutr. 49 (1996) 213-220.

[3] Andrieu J., Aufrère J., Prediction of in vivo organic matter digestibility and net energy value of whole maize plant fed fresh, by laboratory methods (NIRS, chemical, biological and enzymatic), English edition, Colloque maïs ensilage, September 17-18, Nantes, France, Ann Zootech. (1996).

[4] AOAC, Official methods of analysis (14th ed.), Association of Official Analytical Chemists, Washington, DC, 1984.

[5] Aufrère J., Prediction of forage digestibility by an enzymatic method [French], Ann. Zootech. 31 (1982) 111-129.
[6] Aufrère J., Michalet-Doreau B., In vivo digestibility and prediction of digestibility of some by-products. Feeding value of products and their use by beef cattle, EEC Seminar, 26-29 September 1983, Melle-Gontrode, Belgique, 1983.

[7] Baumont R., Barlet A., Jamot J., The ruminal fill effect of forages: its relationship with voluntary intake and study of its laboratory prediction, $3^{\text {es }}$ rencontres autour des recherches sur les ruminants, Paris, France, 4 et 5 décembre 1996, Institut de l'Élevage, Paris, France, 1996, pp. 313-316.

[8] Blummel M., Becker K., The degradability characteristics of fifty-four roughages and roughage neutral-detergent fibres as described by in vitro gas production and their relationship to voluntary feed intake, Brit. J. Nutr. 77 (1997) 757-768.

[9] Blummel M., Bullerdieck P., The need to complement in vitro gas production measurements with residue determinations from in sacco degradabilities to improve the prediction of voluntary intake of hays, Anim. Sci. 64 (1997) 71-75.

[10] Blummel M., Ørskov E.R., Comparison of in vitro gas production and nylon bag degradability of roughages in predicting feed intake in cattle, Anim. Feed Sci. Technol. 40 (1993) 109-119.

[11] Blummel M., Steingass H., Becker K., The partitioning of the in vitro fermentation products and its bearing for the prediction of volontary feed intake, Proceeedings of the Society for Nutrition and Physiology 3 (1994), p. 23.

[12] Blummel M., Steingass H., Becker K., The relationship between in vitro gas production, in vitro microbial biomass yield and ${ }^{15} \mathrm{~N}$ incorporation and its implications for the prediction of voluntary feed intake of roughages, Brit. J. Nutr. 77 (1997) 911-921.

[13] Chenost M., Andrieu J., Aufrère J., Demarquilly C., Some methodological aspects for predicting whole plant maize digestibility from the "gas-test" technique, Options Méditerranéennes, serie A 34 (1997) 137-141.

[14] Cone J.W., Gelder A.H. van., Driehuis F. Description of gas production profiles with a three-phasic model, Anim. Feed Sci. Technol. 66 (1997) 31-45.

[15] Davies A.W., Taylor K., Application of the autoanalyser in a river authority laboratory, Symposium Technicon (1965) 294-300.

[16] Demarquilly C., Jarrige R., Valeur alimentaire de l'herbe des prairies temporaires aux stades d'exploitation pour le paturage. I. Composition chimique et digestibilité, Ann. Zootech. 13 (1964) 301-339.

[17] Demarquilly C., Andrieu J., Wegat-Litre E., Tables de prévision de la valeur alimentaire des fourrages, Prévision de la valeur nutritive des aliments des Ruminants, INRA Publications (Ed.), Versailles (1981), pp. 345-583. 
[18] Dulphy J.P., Jailler M., Jamot J., Bousquet H. An improved laboratory determination of the feeding value of certain hays, Fourrages 12 (1990) 65-78.

[19] Fernandez-Rivera S., Relationships between gas release in vitro and in vivo quality measures of tropical forages, BSAS Occas. Pub. 22 (1998) 36-39.

[20] Getachew G., Blummel M., Makkar H.P.S., Becker K., In vitro gas measuring techniques for assessment of nutritional quality of feeds: a review, Anim. Feed Sci. Technol. 72 (1998) 261-281.

[21] Goodchild A.V., Thomson E.F., Ceccarelli S. Optimizing laboratoty indicators of the nutritive value of straw in decentralized barley straw quality evaluation, Options Méditerranéennes, serie A 34 (1997) 87-92.

[22] Jouany J.P., Dosage des acides gras volatils (AGV) et des alcools dans les contenus digestifs, les jus d'ensilage, les cultures bactériennes et les contenus de fermenteurs anaérobies, Sci. Alim. 2 (1982) 31-144.

[23] Khazaal K., Dentinho M.T., Ribeiro J.M., Ørskov E.R., Prediction of apparent digestibility and voluntary intake of hays fed to sheep: comparison between using fibre components, in vitro digestibility or characteristics of gas production or nylon bag degradation, Anim. Sci. 61 (1995) 527-538

[24] Macheboeuf D., Jestin M., Andrieu J., MartinRosset W., Prediction of the organic matter digestibility of forages in horses by the gas test method, BSAS Occas. Pub. 22 (1998) 252-254.

[25] Macheboeuf D., Jestin M., Martin-Rosset W., Utilization of the gas test method using horse caecal fluid as a source of inoculum, BSAS Occas. Pub. 22 (1998) 187-189.
[26] Makkar H.P.S., Blummel M., Becker K., Formation of complexes between polyvinyl pyrrolidones or polyethylene glycols and tannins, and their implication in gas production and true digestibility in vitro techniques, Brit. J. Nutr. 73 (1995) 897-913.

[27] Menke K.H., Steingass H., Estimation of the energetic feed value obtained from chemical analysis and in vitro gas production using rumen fluid, Anim. Res. Dev. 28 (1988) 7-55.

[28] Menke K.H., Raab L., Salewski A., Steingass H., Fritz D., Schneider W., The estimation of the digestibility and metabolizable energy content of ruminant feedingstuffs from the gas production when they are incubated with rumen liquor in vitro, J. Agric. Sci. 93 (1979) 217-222.

[29] Ørskov E.R., McDonald I., The estimation of protein degradability in the rumen from incubation measurements weighted according to rate of passage, J. Agric. Sci. 92 (1979) 499-503.

[30] Romney D.L., Cadario F.C., Owen E., Murray A.H., Comparison of parameters from the Theodorou gas production technique using nitrogen-free and nitrogenrich media as predictors of DM intake and digestibility, BSAS Occas. Pub. 22 (1998) 172-174.

[31] Sandoval-Castro C.A., Mendoza-Nazar P., In vitro gas production can predict in vivo digestibility but not intake of tropical grass hays, Gas production: Fermentation kinetics for feed evaluation and to assess microbial activity, EAAP Satellite Symposium, Wageningen, 8-19 August 2000, p. 87.

[32] Tilley J.M.A., Terry R.A., A two-stage technique for the digestion of forage crops, J. Brit. Grass. Soc. 18 (1963) 104-111. 